\title{
1
}

\section{From Economic Growth to Wellbeing Economics}

\begin{abstract}
The primary purpose of economics is to contribute to enhanced wellbeing of persons. Economists have often assumed this is best achieved through high economic growth. Nevertheless, experience shows that the pursuit of growth for its own sake can result in policies that harm the wellbeing of large numbers of people. Threats of global climate change, as well as other environmental and social damage caused by current patterns of economic growth, intensify this concern. This first chapter argues for a new framework-wellbeing economics - to guide private and public sector efforts for expanding the capabilities of persons to lead the kinds of lives they value and have reason to value. The wellbeing economics framework focuses on seven types of capital investment at seven levels of human choice. This typology provides the structure for the book's remaining chapters.
\end{abstract}

Keywords Wellbeing $\bullet$ Austerity $\bullet$ Economic growth $\bullet$ Climate change $\bullet$ Capabilities

On 25 November 2010, then Prime Minister David Cameron launched the United Kingdom's Measuring National Wellbeing Programme: "From April next year," he said, "we'll start measuring our progress as a country, not just by 
how our economy is growing, but by how our lives are improving; not just by our standard of living, but by our quality of life" (Cameron 2010, par. 1; see Allin and Hand 2017, for an explanation of the programme and its background). That initiative reflected a wider global trend. Six years earlier, the Australian Treasury had published a wellbeing framework for analysis and policy advice (Treasury 2004; Gorecki and Kelly 2012). In 2008, French President Nicholas Sarkozy had set up the Commission on the Measurement of Economic Performance and Social Progress, headed by Joseph Stiglitz, Amartya Sen and Jean Paul Fitoussi. The unifying theme of its report was: "the time is ripe for our measurement system to shift emphasis from measuring economic production to measuring people's well-being" (Stiglitz et al. 2009, p. 12). In 2010, Italy similarly launched BES (benessere equo e sostenibile), involving multi-dimensional measures of equitable and sustainable wellbeing (CNEL and ISTAT 2010).

At the supranational level, the Organisation for Economic Co-operation and Development has created a wellbeing framework with three pillars: quality of life, material living conditions and sustainability (OECD 2011, 2013, 2015, 2017a). The statistical system of the European Union similarly offers a quality of life framework organised into eight themes of objective wellbeing indicators plus a ninth theme for subjective or self-evaluated measures (Eurostat 2015). The World Bank (2016) has compiled 1300 data series as indicators of global development and the quality of people's lives in more than 200 countries. The 2030 Agenda for Sustainable Development includes a vision of a world where physical, mental and social wellbeing are assured (United Nations 2015, par. 7).

These developments are consistent with a long tradition in economics that aims to promote the wellbeing of people. Consider, for example, the critique of mercantilism in Adam Smith's Wealth of Nations, the book that founded modern economics (Smith 1776, Volume 2, p. 179):

Consumption is the sole end and purpose of all production; and the interest of the producer ought to be attended to, only so far as it may be necessary for promoting that of the consumer. The maxim is so perfectly self-evident, that it would be absurd to attempt to prove it. But in the mercantile system the interest of the consumer is almost constantly sacrificed to that of the producer; and it seems to consider production, and not consumption, as the ultimate end and object of all industry and commerce.

Another prominent example was the Cambridge professor, Alfred Marshall, who removed economics from the Moral Sciences and History Tripos to make it an independent discipline (Groenewegen 1995, Chap. 15). As quoted by Keynes 
(1924, p. 319), Marshall chose economics as his lifetime study because he wanted to address systematic causes of poverty:

"From Metaphysics I went to Ethics, and thought that the justification of the existing condition of society was not easy. A friend, who had read a great deal of what are now called the Moral Sciences, constantly said: 'Ah! if you understood Political Economy you would not say that.' So I read Mill's Political Economy and got much excited about it. I had doubts as to the propriety of inequalities of opportunity, rather than of material comfort. Then, in my vacations I visited the poorest quarters of several cities and walked through one street after another, looking at the faces of the poorest people. Next, I resolved to make as thorough a study as I could of Political Economy."

Other examples could be provided, but the point is made: economists have long understood that the primary purpose of the discipline is to contribute to enhanced wellbeing of persons. ${ }^{1}$ The wellbeing economics framework is founded on this understanding, expressed as the first of 24 propositions set out in this book to describe key points in the framework (the propositions can be read together in the first section of Chap. 9):

Proposition 1 The primary purpose of economics is to contribute to enhanced wellbeing of persons.

In the same year that the Measuring National Wellbeing Programme was launched, the British government imposed austerity measures that included cutbacks in annual social welfare spending of $£ 11$ billion, reductions in other areas of government spending of $£ 21$ billion, an increase in value added tax and a two-year freeze in public sector pay for those earning more than $£ 21,000$ per annum (HM Treasury 2010). These austerity measures were expanded in subsequent years. The 2014 Budget included a welfare cap to limit total welfare spending, for example, while the 2015 Budget announced further reductions in government spending of $£ 30$ billion over 2 years (HM Treasury 2014, 2015).

There was a sharp rise in the number of charity food banks after these policies, among other indicators of increased social distress (Jackson 2015; Loopstra et al. 2015; O'Hara 2015, Chap. 1; Purdam et al. 2015; Garthwaite 2016). This leads to an obvious question: if the primary purpose of economics is to contribute to enhanced wellbeing of persons, and if the government's stated intention is to measure progress by how our lives are improving, how can policymakers justify austerity and other economic policies that result in such high levels of increased suffering? 


\section{Wellbeing and Economic Growth}

Economists typically answer this question in three steps. First, it is argued that wellbeing is enhanced when individuals can satisfy more of their personal preferences, perhaps because they can afford a wider range of choices (Dolan and Peasgood 2008; Hausman and McPherson 2009). Hence, wellbeing is improved if a policy allows some people to increase preference satisfaction without anyone facing reduced choices (Pareto 1906; Hicks 1939). Such a policy is said to increase Pareto efficiency.

This seldom occurs in practice, since policies typically create losers as well as winners. The analysis may suggest, however, that the winners could fully compensate the losers and still be better off. Even if the compensation is not paid in practice, such a policy is likely to be considered reasonable. This is because wins and losses experienced by an individual from all policy changes over a lifetime, if randomly distributed, might be expected to produce an overall gain when all policy changes meet this criterion (Hicks 1941).

The second step argues that economic growth is a dominant example of what provides the general population with a greater range of choices and allows more preferences to be satisfied. A famous observation by Nobel laureate Robert Lucas illustrates the significance attributed to growth as a source of wellbeing. After noting that there is a large spread between the growth rates of countries, Lucas (1988, p. 5) commented:

Is there some action a government of India could take that would lead the Indian economy to grow like Indonesia's or Egypt's? If so, what, exactly? If not, what is it about the 'nature of India' that makes it so? The consequences for human welfare involved in questions like these are simply staggering: Once one starts to think about them, it is hard to think about anything else.

Thus, although wellbeing may be the ultimate objective, policy priorities typically focus on achieving higher economic growth as the best means for expanding wellbeing in the long-term. Indeed, this was emphasised at the launch of the United Kingdom's Measuring National Wellbeing Programme, when the Prime Minister addressed concerns that it sidelined economic growth (Cameron 2010, par. 4, emphasis added):

Now, let me be very, very clear: growth is the essential foundation of all our aspirations. Without a job that pays a decent wage, it is hard for people to look after their families in the way they want, whether that's taking the children on holiday or 
making your home a more comfortable place. Without money in your pocket it is difficult to do so many of the things we enjoy, from going out in the evening to shopping at the weekend. So, at this time I am absolutely clear that our most urgent priority is to get the economy moving, to create jobs, to spread opportunity for everyone.

The third step argues that economic growth requires specific policies to be implemented. The austerity measures, for example, were justified in precisely these terms (HM Treasury 2010, p. 1):

The most urgent task facing this country is to implement an accelerated plan to reduce the deficit. Reducing the deficit is a necessary precondition for sustained economic growth.

Economists devote considerable effort to exploring how to foster economic growth (Jones and Vollrath 2013). A major advance was Robert Solow's (1956) neoclassical growth model, which demonstrated how countries tend to achieve higher levels of output per person if they have a higher rate of investment in physical capital such as factories, plant and machinery. ${ }^{2}$ Solow's model also shows how output per person tends to grow more quickly with higher growth in labour productivity (that is, faster increases in the average value of output per hour of work, which indicates a country's rate of technological progress).

Important extensions have been made to the neoclassical growth model. Mankiw et al. (1992) demonstrated that education levels of the workforce are an important factor influencing labour productivity, while Knowles and Owen (1995) demonstrated the importance of good health. More profoundly, Romer $(1986,1990)$ incorporated the idea that technological progress is influenced by the amount of effort devoted to producing new knowledge. His insight led to a new class of endogenous growth models, which will be discussed in this book's Chap. 7.

Economists also explore the role of social institutions and norms in supporting economic growth (North 1987; Rodrik et al. 2004). In his Nobel Prize lecture, Douglass North (1994) pointed out that the neoclassical growth model does not apply in countries lacking the necessary institutions for markets to operate. An important example is that effective legal protections for property rights are essential for strong economic growth (La Porta et al. 2008; Xu 2011). Some studies emphasise social values such as trust (Fukuyama 1995; Quddus et al. 2000; McCloskey 2010), while others focus on good government and good governance (Krueger 1990; Kaufmann et al. 1999; Hulme et al. 2015) 
including strict requirements for macroeconomic stability (Fischer 1991; Fatás and Mihov 2013).

This research has created a consensus among economists about what constitutes good economic policy, represented for example by the contents of the Going for Growth report published annually by the OECD (2017b). Taking these arguments together, the promise is that orthodox economic policies will increase growth of per capita real gross domestic product (GDP), which will allow individuals to increase the range of their choices, which will promote wellbeing. This is the vision behind statements such as the one cited above from David Cameron that growth is the essential foundation of all our aspirations.

Experience shows, however, that economic growth cannot always be relied upon to improve wellbeing. Referring to Cameron's examples, it is possible to have economic growth without new jobs paying a decent wage, without people finding it easier to look after their families in the way they want and without opportunity for everyone. Indeed, a country can experience economic growth at the same time that large groups in the population find they are unable to maintain their material living standards.

\section{The Limits to Growth}

The title of this section comes from a famous report prepared in the early 1970 s by researchers at the Massachusetts Institute of Technology. Building on a tradition going back at least to Ricardo (1817, Chap. 2), the report examined interconnections between accelerating industrialisation, rapid population growth, widespread malnutrition, depletion of non-renewable resources and a deteriorating environment (Meadows et al. 1972). Its analysis of prevailing trends led the research team to conclude that "the limits to growth on this planet will be reached sometime within the next one hundred years" (idem, p. 23). ${ }^{3}$

Modern studies continue to find evidence that persistent production growth is inconsistent with finite resources (Meadows et al. 2005; Hall and Day 2009; Rockström et al. 2009a, b; Nørgård et al. 2010; Bardi 2011; Turner 2012; Jackson and Webster 2016). Not only does increasing material consumption put pressure on the planet's non-renewable resources, but also natural ecosystems have limited capacities to absorb higher pollution associated with economic growth, including accumulating greenhouse gas emissions. The Intergovernmental Panel on Climate Change makes the following key observation (IPCC 2015, p. 4, emphasis added): 
Anthropogenic greenhouse gas emissions have increased since the pre-industrial era, driven largely by economic and population growth, and are now higher than ever. This has led to atmospheric concentrations of carbon dioxide, methane and nitrous oxide that are unprecedented in at least the last 800,000 years. Their effects, together with those of other anthropogenic drivers, have been detected throughout the climate system and are extremely likely to have been the dominant cause of the observed warming since the mid-20th century.

The lesson from this research is that how economies grow is vital for wellbeing. Indeed, if current patterns of economic production continue, the planet's surface is likely to be in the order of $3^{\circ} \mathrm{C}$ to $5^{\circ} \mathrm{C}$ warmer by 2050 , creating considerable risks such as damage to unique ecosystems and more frequent extreme weather events (IPCC 2015, p. 18). Thus, the claim that "growth is the essential foundation of all our aspirations" is false.

Tim Jackson $(2009,2017)$ argues that policy needs to consider prosperity without growth. He defines prosperity as an ability to flourish as human beings, which certainly involves material dimensions, but much more (Jackson 2017, p. 212):

To do well is in part about the ability to give and receive love, to enjoy the respect of our peers, to contribute usefully to society, to have a sense of belonging and trust in the community, to help create the social world and find a credible place in it. In short, an important component of prosperity is the ability to participate meaningfully in the life of society.

Jackson therefore advocates policies that target flourishing directly, rather than aiming for economic growth as an intermediate step. Since flourishing depends on our natural environment, this must include respect for the planet's ecological limits. Current economic growth trajectories are imposing ecological costs on future generations that will threaten wellbeing on a global scale. Jackson therefore appeals for a new macroeconomics in which economic activity is constrained to stay within sustainable limits (idem, p. 160). ${ }^{4}$

These concerns are amplified by the way in which growth is currently measured; that is, as percentage increases in GDP. The rules for calculating GDP are set out in the United Nations System of National Accounts (United Nations 2009), which sets boundaries on what categories of economic activity are included in the measure. Certain forms of unpaid work are excluded, such as care for children by parents within their own households. Also excluded is most environmental damage caused by economic production. 
An early critique of these rules was made by Marilyn Waring (1988). ${ }^{5}$ As a member of the New Zealand Parliament between 1975 and 1984, Waring saw the results of policy being based on claims such as "growth is the essential foundation of all our aspirations", when growth is defined narrowly by GDP. Policies focus on activities included within the GDP boundaries, and so other dimensions of wellbeing, including the natural environment, are sacrificed in the pursuit of measured growth.

Herman Daly and John Cobb (1989) similarly argued that GDP cannot measure genuine economic progress. They created an index of sustainable economic welfare (ISEW) to include considerations such as distributional inequality, household production for own consumption and degraded natural environments. Daly and Cobb showed that the average growth in the ISEW for the United States is substantially below the growth rate of GDP (idem, p. 453). Similar conclusions have been reached for other countries using either the ISEW or variants such as the genuine progress indicator and the sustainable net benefit index. ${ }^{6}$

An important example of how a focus on GDP growth can overlook deteriorating trends in aspects of wellbeing, highlighted in Daly and Cobb's original analysis, is widening income inequality. This remains an urgent concern three decades later, with numerous recent studies presenting evidence on rising inequality and associated losses of wellbeing (Wilkinson and Pickett 2009; Stiglitz 2012; Piketty 2013; Atkinson 2015; Marmot 2015). This phenomenon is not visible to policy advisors if the dominant measure of policy success is growth in GDP.

In short, it is not reasonable to presume that GDP growth, regardless of the nature of that growth, will increase wellbeing. Indeed, certain patterns of growth can cause harm to wellbeing, and so economics must recover a deeper understanding of how wellbeing is enhanced. ${ }^{7}$ A good starting point is the capabilities approach developed by Amartya Sen.

\section{Wellbeing and Capabilities}

Consistent with the focus of economists on growth, Walt Rostow (1960) famously defined development as a process of countries moving through five stages of rising economic growth: (1) living in traditional society; (2) creating the pre-conditions for take-off; (3) achieving take-off; (4) driving to maturity; and (5) enjoying high mass consumption. Reacting to that theory, Amartya Sen offered an alternative understanding based on what people are able to do in their lives (Sen 1983, p. 754): 
Ultimately, the process of economic development has to be concerned with what people can or cannot do, e.g. whether they can live long, escape avoidable morbidity, be well nourished, be able to read and write and communicate, take part in literary and scientific pursuits, and so forth.

Sen's conceptualisation of development is known as the "capabilities approach" (Nussbaum 2000, 2011; Alkire 2002; Robeyns 2006; Schischka et al. 2008). The core idea is captured in the following short extract from Sen's influential book, Development as Freedom (Sen 1999a, p. 18):

The analysis of development presented in this book treats the freedoms of individuals as the basic building blocks. Attention is thus paid particularly to the expansion of the 'capabilities' of persons to lead the kinds of lives they value - and have reason to value.

Note how Sen refers to persons, rather than people (which can indicate a mass of indistinguishable humans) or individuals (which can suggest an actor in isolation from all others). We follow that usage throughout this book, to convey that persons are simultaneously social beings and unique personalities. The capabilities approach is reflected in our second proposition.

Proposition 2 Wellbeing can be enhanced by expanding the capabilities of persons to lead the kinds of lives they value, and have reason to value.

Presented originally in the context of development studies, this approach has been adopted in more general studies of wellbeing (Sen 1993; Clark 2005). Sen was a member of the Commission on the Measurement of Economic Performance and Social Progress (Stiglitz et al. 2009), where his research was highly influential. The capabilities approach was applied in the design of the Australian Treasury's wellbeing framework (Henry 2006, pp. 6-7) and the design of the New Zealand Treasury's higher living standards framework (Gleisner et al. 2011, pp. 11-13). Jackson (2009, pp. 43-47) recognises that Sen's approach resonates with his own vision of prosperity, emphasising that development of human capabilities must also respect ecological limits.

A feature of Sen's approach, reflected in his quote above, is that persons make their own judgements about what constitutes a valued kind of life, but judgements must be supported by reason. Thus, Sen does not identify wellbeing with satisfying individual preferences, or with the unreflective preferences of groups of individuals. Instead, his formulation highlights the value of contested and 
dynamic processes of communal reasoning, particularly in determining how public policy can contribute to enhanced wellbeing (see also Sen 1999b; White 2017, pp. 124-125).

Proposition 2 invites policies that aim to expand capabilities, rather than to increase economic growth for its own sake. This mirrors Adam Smith's point at the beginning of this chapter: it is not production that is important, but the wellbeing of consumers. The approach taken in this book is inspired by Solow's (1956) neoclassical growth model, but expanded to address a wider range of capabilities and wellbeing outcomes. Solow demonstrated that investment in physical capital can increase a country's material living standards. That result is consistent with Sen's theory, since construction of new assets such as buildings, machinery and roads can be conceptualised as expanding the capabilities of persons who use those assets.

Similarly, investment in other types of enduring assets-non-material as well as material—can improve wellbeing outcomes by expanding the capabilities of persons to lead valued lives. Each of these asset types can be described using "capital" as a metaphor (see, for example, Flora and Flora 2007; Arrow et al. 2012; IIRC 2013; Gleeson-White 2014). The wellbeing economics framework focuses on seven types of capital stock, listed in Table 1.1. Details will be explained in later chapters of the book, but are introduced briefly here.

Mincer (1958), Shultz (1960, 1961) and Becker (1962,1964) coined the term "human capital" to describe participation in formal education, which has similar characteristics to investment in physical capital by requiring the sacrifice of current consumption to increase future income. Cultural capital refers to a

Table 1.1 Types of capital in the wellbeing economics framework

\begin{tabular}{|c|c|}
\hline Capital & Examples of the Associated Capital Investment \\
\hline Human & $\begin{array}{l}\text { Developing personal skills through participation in education, through } \\
\text { experience and through better health. }\end{array}$ \\
\hline Cultural & $\begin{array}{l}\text { Inheriting, practicing, transforming and passing on values from } \\
\text { generation to generation. }\end{array}$ \\
\hline Social & $\begin{array}{l}\text { Strengthening diverse networks, voluntary organisations and bonds of } \\
\text { trust within and between communities. }\end{array}$ \\
\hline Economic & $\begin{array}{l}\text { Constructing and owning enduring human-made physical and financial } \\
\text { assets. }\end{array}$ \\
\hline Natural & $\begin{array}{l}\text { Conserving wilderness and managed natural areas to maintain or } \\
\text { improve the environment's ecosystem services. }\end{array}$ \\
\hline Knowledge & $\begin{array}{l}\text { Researching and developing advances in technology and other } \\
\text { intellectual property products. }\end{array}$ \\
\hline Diplomatic & $\begin{array}{l}\text { Cultivating institutions and norms that foster international } \\
\text { collaboration for the common good. }\end{array}$ \\
\hline
\end{tabular}


community's values and practices that are transformed and passed down from generation to generation (Bourdieu 1983; Throsby 1999). Social capital describes diverse networks, voluntary organisations and bonds of trust that exist within and between communities (Coleman 1986; Putnam 1995).

Economic capital encompasses the stock of physical capital and its ownership in the form of stocks, shares, debentures and other forms of financial capital (OECD 2015, pp. 129-137). Natural capital recognises that ecological environments are the setting for much human activity, which needs ongoing investment to be maintained (Helm 2015). Knowledge capital refers to technological discoveries and other forms of intellectual property, some of which may be recorded as assets in balance sheets (Nahapiet and Ghoshal 1998; Guthrie et al. 2012). Diplomatic capital is a term used in this book to describe organisations and norms needed for international collaboration to promote the global common good.

For each capital type in Table 1.1, the stock of capital provides flows of services important for wellbeing. Human capital provides the person who possesses it with skills that can be displayed in employment or other contributions to wellbeing. Cultural capital and social capital help give meaning to life and make social transactions easier. Economic capital increases labour productivity and offers financial returns to savers. Natural capital provides ecosystem services that are often irreplaceable for wellbeing. Drawing on knowledge capital allows people to do more with less, and the use of diplomatic capital helps the global community address some of the most pressing issues facing humanity.

A second dimension of the wellbeing economics framework recognises that choices affecting wellbeing are made at different levels of social interaction. Figure 1.1 provides a structure for considering these different scales. It shows levels of human choice that involve larger and larger numbers of people as the choices move outwards from the individual to the global community.

The diagram begins in the innermost oval with persons making choices about activities that contribute to the kind of life they value and have reason to value. Persons come together to form households and families, which gives rise to a second level of choices. Outside the home, people form community organisations to advance cultural, sporting, political, economic and other purposes; these organisations make up civil society. As market participants, people make choices as producers and as consumers of goods and services.

A household's place of residence typically has local government providing public services for the diverse individuals and communities living in that locality. The Nation State exercises authority on behalf of, but also over, citizens, 


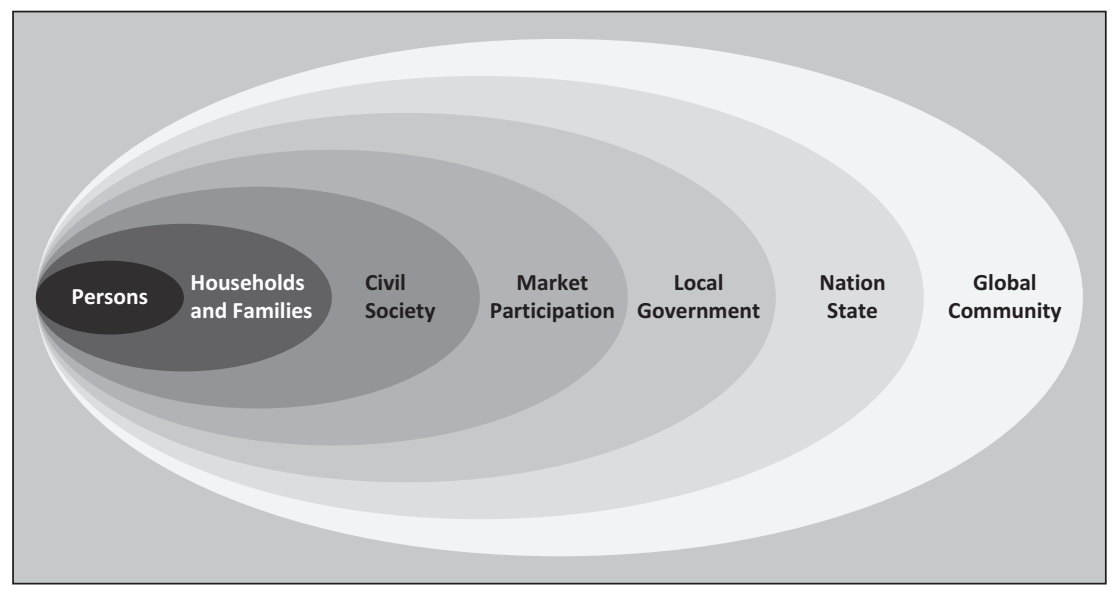

Fig. 1.1 Levels of human choice in the wellbeing economics framework

producing potential tensions in how choices at the national policy level support or interfere with choices at other levels. Finally, some of the biggest issues affecting wellbeing (such as the threats of global climate change) require negotiated choices among international partners, including governmental and non-governmental organisations, acting globally.

A key task of wellbeing economics is to integrate the different levels of human choice represented in Fig. 1.1 with the different types of capital investment listed in Table 1.1. Investment in human capital, for example, may be made by an individual person, whereas growth in diplomatic capital requires global collaboration. The two dimensions of the framework are therefore brought together in the final proposition of this chapter.

Proposition 3 The capabilities of persons can be expanded by different types of capital investment at different levels of human choices.

\section{Conclusion}

Despite greater attention to measuring wellbeing, it is still common for the current wellbeing of some citizens to be sacrificed by policies intended to promote GDP growth. This practice ignores wider social issues important for wellbeing and is inconsistent with environmental limits to economic growth. Consequently, 
this book sets out to recover from the economics tradition what it calls the wellbeing economics framework.

The three propositions in this chapter are foundational for the framework. The primary purpose of economics is to contribute to enhanced wellbeing of persons (Proposition 1). This can be achieved by expanding the capabilities of persons to lead the kinds of lives they value and have reason to value (Proposition 2). This can be done through different types of capital investment at different levels of human choice (Proposition 3). Thus, wellbeing is affected not only by growth in all the different types of capital available in a country, but also by the ability of different groups in the population to access services provided by the country's capital stocks. This book returns repeatedly to these two issues.

Inspired by Amartya Sen's research on capabilities, the book is structured around two dimensions of economic activity: the different levels of human choice set out in Fig. 1.1; and the different types of capital investment set out in Table 1.1. Each of the following seven chapters focuses on one level of human choice and on one type of capital investment, guided by natural associations between these classifications.

Decisions about the number of years devoted to investing in human capital, for example, can be sensibly discussed in the context of persons making time-use choices; this is done in Chap. 2. Transmission of cultural capital across generations fits comfortably with choices made by persons living in families and households; this is addressed in Chap. 3. Social capital and the institutions of civil society are almost synonymous; see Chap. 4. A large literature on economic capital investment in the context of market participation is summarised in Chap. 5.

The book then turns to political institutions in the public sphere. Local government is typically required to maintain and enhance a locality's natural capital, considered in Chap. 6. There is considerable research on the role of a Nation State to support the development of intellectual property, which is explored in Chap. 7. Diplomatic capital is essential for cultivating collaboration by intergovernmental and non-governmental organisations in the global community; this topic is approached in Chap. 8.

In each case, the chapter draws insights from the economics literature to analyse how wellbeing can be enhanced, not just by public policy, but at all levels of human choice. Chapter 9 then integrates these different elements to introduce a wellbeing fabric for policy analysis. It demonstrates how wellbeing economics can contribute to expanding human capabilities for living the kinds of lives we value and have reason to value. 


\section{Notes}

1. This tradition continues: welfare economics is an established field, for example, and students majoring in economics are routinely required to demonstrate they can use mathematics to prove the Fundamental Theorems of Welfare Economics (Blaug 2007, p. 198).

2. Trevor Swan (1956) independently published a model of economic growth with similar results to Solow's more influential version.

3. There was an immediate reaction from economists, including from Solow (1974a, b) who argued this can be avoided by investment in physical capital to replace the depleted natural resources. Hartwick (1977) calculated the exact rate of physical capital investment that would allow sustainable growth. That response continues to be developed in research programmes on genuine savings and comprehensive wealth (World Bank 2011; Arrow et al. 2012; Hanley et al. 2015).

4. Macroeconomics deals with country-level outcomes such as economic growth. An interesting example of research on macroeconomics that respects ecological limits is Fontana and Sawyer (2016). An influential analysis of planetary boundaries can be found in Rockström et al. (2009a, b).

5. Recent reviews are provided by Bjørnholt and McKay (2014) and by Saunders and Dalziel (2017). Coyle (2014) presents a sympathetic account of GDP.

6. Lawn (2003) offers an overview of these measures.

7. This is recognised by others, of course. In the United Kingdom, mention should be made of initiatives such as the All-Party Parliamentary Group on Wellbeing Economics formed in March 2009 and legislation such as the Well-being of Future Generations (Wales) Act 2015.

\section{References}

Alkire, Sabina. 2002. Valuing Freedoms: Sen's Capability Approach and Poverty Reduction. Oxford: Oxford University Press.

Allin, Paul, and David J. Hand. 2017. New Statistics for Old? - Measuring the Wellbeing of the UK. Journal of Royal Statistical Society A 180 (Part 1): 3-43.

Arrow, Kenneth J., Partha Dasgupta, Lawrence H. Goulder, Kevin J. Mumford, and Kirsten Oleson. 2012. Sustainability and the Measurement of Wealth. Environment and Development Economics 17 (3): 317-353.

Atkinson, Anthony B. 2015. Inequality: What Can Be Done? Cambridge, MA: Harvard University Press.

Bardi, Ugo. 2011. The Limits to Growth Revisited. New York: Springer.

Becker, Gary. 1962. Investment in Human Capital: A Theoretical Analysis. Journal of Political Economy 70 (5, Part 2): 9-49. 
-1964. Human Capital: A Theoretical and Empirical Analysis, with Special Reference to Education. New York: Columbia University Press.

Bjørnholt, Margunn, and Ailsa McKay, eds. 2014. Counting on Marilyn Waring: New Advances in Feminist Economics. Bradford, Ontario: Demeter Press.

Blaug, Mark. 2007. The Fundamental Theorems of Modern Welfare Economics, Historically Contemplated. History of Political Economy 39 (2): 185-207.

Bourdieu, Pierre. 1983. Ökonomisches Kapital, Kulturelles Kapital, Soziales Kapital. In Soziale Ungleichheiten (Soziale Welt, Sonderheft 2), ed. Reinhard Kreckel, 183-198. Goettingen: Otto Schartz. Trans. Richard Nice and republished as The Forms of Capital in Handbook of Theory and Research for the Sociology of Education, ed. John C. Richardson, 241-258. Westport: Greenwood Publishing Group, 1986.

Cameron, Rt. Hon. David. 2010. PM Speech on Wellbeing. A transcript of a speech given by the Prime Minister on 25 November 2010. https://www.gov.uk/government/speeches/pm-speech-on-wellbeing.

Clark, David A. 2005. Sen's Capability Approach and the Many Spaces of Human Wellbeing. Journal of Development Studies 41 (8): 1339-1368.

CNEL and ISTAT. 2010. CNEL and ISTAT Measure Well-being: Set of Indicators to be Identified by 2011. Press Release. http://www.istat.it/en/archive/10128.

Coleman, James S. 1986. Social Capital in the Creation of Human Capital. American Journal of Sociology 94 (Supplement): S95-S120.

Coyle, Diane. 2014. GDP: A Brief but Affectionate History. Princeton and Oxford: Princeton University Press.

Daly, Herman E., and John B. Cobb Jr. 1989. For the Common Good: Redirecting the Economic toward Community, the Environment, and a Sustainable Future. Boston: Beacon Press.

Dolan, Paul, and Tessa Peasgood. 2008. Measuring Well-being for Public Policy: Preferences or Experiences? Journal of Legal Studies 37 (S2): S5-S31.

Eurostat. 2015. Quality of Life: Facts and Figures. Eurostat Statistical Books.

Fatás, Antonio, and Ilian Mihov. 2013. Policy Volatility, Institutions, and Economic Growth. Review of Economics and Statistics 95 (2): 362-376.

Fischer, Stanley. 1991. Growth, Macroeconomics, and Development. In NBER Macroeconomics Annual, ed. Olivier Jean Blanchard and Stanley Fischer, vol. 6, 329379. Cambridge, MA: MIT Press.

Flora, Cornelia Butler, and Jan L. Flora. 2007. Rural Communities: Legacy and Change. 3rd ed. Boulder, CO: Westview Press.

Fontana, Giuseppe, and Malcolm Sawyer. 2016. Towards Post-Keynesian Ecological Economics. Ecological Economics 121: 186-195.

Fukuyama, Francis. 1995. Trust: The Social Virtues and the Creation of Prosperity. New York: Free Press.

Garthwaite, Kayleigh. 2016. Hunger Pains: Life inside Foodbank Britain. Bristol: Policy Press. 
Gleeson-White, Jane. 2014. Six Capital: The Revolution Capitalism Has to Have - Or Can Accountants Save the Planet. Sydney: Allen \& Unwin.

Gleisner, Ben, Mary Llewellyn-Fowler, and Fiona McAlister. 2011. Working Towards Higher Living Standards for New Zealanders. New Zealand Treasury Paper 11/02. Wellington: Treasury.

Gorecki, Stephanie, and James Kelly. 2012. Treasury's Wellbeing Framework. Economic Roundup 3: 27-64.

Groenewegen, Peter. 1995. A Soaring Eagle: Alfred Marshall 1842-1924. Cheltenham: Edward Elgar.

Guthrie, James, Federica Ricceri, and John Dumay. 2012. Reflections and Projections: A Decade of Intellectual Capital Accounting Research. The British Accounting Review 44 (2): 68-82.

Hall, Charles A.S., and John W. Day Jr. 2009. Revisiting the Limits to Growth After Peak Oil. American Scientist 97 (May-June): 230-237.

Hanley, Nick, Louis Dupuy, and Eoin McLaughlin. 2015. Genuine Savings and Sustainability. Journal of Economic Surveys 29 (4): 779-806.

Hartwick, John M. 1977. Intergenerational Equity and the Investing of Rents from Exhaustible Resources. American Economic Review 67 (5): 972-974.

Hausman, Daniel M., and Michael S. McPherson. 2009. Preference Satisfaction and Welfare Economics. Economics and Philosophy 25 (1): 1-25.

Helm, Dieter. 2015. Natural Capital: Valuing the Planet. New Haven and London: Yale University Press.

Henry, Ken. 2006. Wellbeing and Public Policy. Presentation to the Population Wellbeing Data Gaps Workshop, Australian Bureau of Statistics, Canberra, 8 June.

Hicks, John R. 1939. The Foundations of Welfare Economics. Economic Journal 49 (196): 696-712.

- 1941. The Rehabilitation of Consumer' Surplus. Review of Economic Studies 8 (2): $108-116$.

HM Treasury. 2010. Budget 2010. House of Commons document HC61. London: The Stationery Office.

- 2014. Budget 2014. House of Commons document HC1104. London: The Stationery Office.

- 2015. Budget 2015. House of Commons document HC1093. London: The Stationery Office.

Hulme, David, Antonio Savoia, and Kunal Sen. 2015. Governance as a Global Development Goal? Setting, Measuring and Monitoring the Post-2015 Development Agenda. Global Policy 6 (2): 85-96.

IIRC. 2013. The International <IR> Framework. London: The International Integrated Reporting Council.

IPCC. 2015. Climate Change 2014: Synthesis Report. Contribution of Working Groups I, II and III to the Fifth Assessment Report of the Intergovernmental Panel on Climate Change. Geneva: Intergovernmental Panel on Climate Change. 
Jackson, Tim. 2009. Prosperity without Growth: Economics for a Finite Planet. London: Earthscan.

Jackson, Trevor. 2015. Austerity and the Rise of Food Banks. BMJ 350. https://doi. org/10.1136/bmj.h1880.

Jackson, Tim. 2017. Prosperity without Growth: Foundations for the Economy of Tomorrow. 2nd ed. Abingdon/New York: Routledge.

Jackson, Tim, and Robin Webster. 2016. Limits Revisited: A Review of the Limits to Growth Debate. Report prepared for the All-Party Parliamentary Group on Limits to Growth. http://limits2growth.org.uk/revisited/. Accessed 15 Aug 2016.

Jones, Charles I., and Dietrich Vollrath. 2013. Introduction to Economic Growth. 3rd ed. New York: W. W. Norton.

Kaufmann, Daniel, Aart Kraay, and Pablo Zoido-Lobatón. 1999. Governance Matters. Policy Research Working Paper 2196. Washington, DC: World Bank.

Keynes, John Maynard. 1924. Alfred Marshall, 1842-1924. Economic Journal 34 (135): 311-372.

Knowles, Stephen, and P. Dorian Owen. 1995. Health Capital and Cross-country Variation in Income per Capita in the Mankiw-Romer-Weil Model. Economics Letters 48 (1): 99-106.

Krueger, Anne O. 1990. Government Failures in Development. Journal of Economic Perspectives 4 (3): 9-23.

La Porta, Rafael, Florencio Lopez-de-Silanes, and Andrei Shleifer. 2008. The Economic Consequences of Legal Origins. Journal of Economic Literature 46 (2): 285-332.

Lawn, Philip A. 2003. A Theoretical Foundation to Support the Index of Sustainable Economic Welfare (ISEW), Genuine Progress Indicator (GPI), and Other Related Indexes. Ecological Economics 44 (1): 105-118.

Loopstra, Rachel, Aaron Reeves, David Taylor-Robinson, Ben Barr, Martin McKee, and David Stuckler. 2015. Austerity, Sanctions, and the Rise of Food Banks in the UK. BMJ 350. https://doi.org/10.1136/bmj.h1775.

Lucas, Robert E., Jr. 1988. On the Mechanics of Economic Development. Journal of Monetary Economics 22 (1): 3-42.

Mankiw, N. Gregory, David Romer, and David N. Weil. 1992. A Contribution to the Empirics of Economic Growth. Quarterly Journal of Economics 107 (2): 407-437.

Marmot, Michael. 2015. The Health Gap: The Challenge of an Unequal World. London: Bloomsbury Publishing.

McCloskey, Deirdre. 2010. Bourgeois Dignity: Why Economics Can't Explain the Modern World. Chicago: Chicago University Press.

Meadows, Donella H., Dennis L. Meadows, Jørgen Randers, and William W. Behrens III. 1972. The Limits to Growth. New York: Universe Books.

Meadows, Donella, Jørgen Randers, and Dennis Meadows. 2005. The Limits to Growth: The 30-Year Update. London: Earthscan.

Mincer, Jacob. 1958. Investment in Human Capital and Personal Income Distribution. Journal of Political Economy 66 (4): 281-302. 
Nahapiet, Janine, and Sumantra Ghoshal. 1998. Social Capital, Intellectual Capital, and the Organizational Advantage. Academy of Management Review 23 (2): 242-266.

Nørgård, Jørgen Stig, John Peet, and Kristín Vala Ragnarsdóttir. 2010. The History of The Limits to Growth. Solutions 1 (2): 59-63.

North, Douglass C. 1987. Institutions, Transaction Costs and Economic Growth. Economic Inquiry 25 (3): 419-428.

- 1994. Economic Performance through Time. American Economic Review 84 (3): 359-368.

Nussbaum, Martha C. 2000. Women and Human Development: The Capabilities Approach. Cambridge: Cambridge University Press.

- 2011. Creating Capabilities: The Human Development Approach. Cambridge, MA: Belknap Press.

O'Hara, Mary. 2015. Austerity Bites: A Journey to the Sharp End of Cuts in the UK. Bristol: Policy Press.

OECD. 2011. How's Life? Measuring Well-being. Paris: OECD Publishing. https://doi. org/10.1787/9789264121164-en.

- 2013. How's Life? 2013: Measuring Well-being. Paris: OECD Publishing. https:// doi.org/10.1787/9789264201392-en.

- 2015. How's Life? 2015: Measuring Well-being. Paris: OECD Publishing. https:// doi.org/10.1787/how_life-2015-en.

- 2017a. How's Life? 2017: Measuring Well-being. Paris: OECD Publishing. https://doi.org/10.1787/how_life-2017-en.

- 2017b. Economic Policy Reforms: Going for Growth 2017. Paris: OECD Publishing. https://doi.org/10.1787/growth-2017-en.

Pareto, Vilfredo. 1906. Manuale di Economia Politica. Milan: Societa Editrice Libraria.

Piketty, Thomas. 2013. Capital in the Twenty-First Century. Trans. Arthur Goldhammer. Cambridge, MA: Harvard University Press.

Purdam, Kingsley, Elizabeth A. Garratt, and Aneez Esmail. 2015. Hungry? Food Insecurity, Social Stigma and Embarrassment in the UK. Sociology, published online. https://doi.org/10.1177/0038038515594092.

Putnam, Robert D. 1995. Bowling Alone: America's Declining Social Capital. Journal of Democracy 6 (1): 65-78.

Quddus, Munir, Michael Goldsby, and Mahmud Farooque. 2000. Trust: The Social Virtues and the Creation of Prosperity-A Review Article. Eastern Economic Journal 26 (1): 87-98.

Ricardo, David. 1817. On the Principles of Political Economy and Taxation. London: John Murray.

Robeyns, Ingrid. 2006. The Capability Approach in Practice. Journal of Political Philosophy 14 (3): 351-376.

Rockström, Johan, Will Steffen, Kevin Noone, Åsa Persson, F. Stuart Chapin III, Eric Lambin, Timothy M. Lenton, Marten Scheffer, Carl Folke, Hans Joachim Schellnhuber, Björn Nykvist, Cynthia A. de Wit, Terry Hughes, Sander van der Leeuw, Henning Rodhe, Sverker Sörlin, Peter K. Snyder, Robert Costanza, Uno 
Svedin, Malin Falkenmark, Louise Karlberg, Robert W. Corell, Victoria J. Fabry, James Hansen, Brian Walker, Diana Liverman, Katherine Richardson, Paul Crutzen, and Jonathan Foley. 2009a. Planetary Boundaries: Exploring the Safe Operating Space for Humanity. Ecology and Society 14 (2): 32 [online] URL: http://www.ecologyandsociety.org/vol14/iss $2 /$ art32/.

. 2009b. A Safe Operating Space for Humanity. Nature 461: 472-475.

Rodrik, Dani, Arvind Subramanian, and Francesco Trebbi. 2004. Institutions Rule: The Primacy of Institutions over Geography and Integration in Economic Development. Journal of Economic Growth 9 (2): 131-165.

Romer, Paul M. 1986. Increasing Returns and Long-Run Growth. Journal of Political Economy 94 (5): 1002-1037.

— 1990. Endogenous Technological Change. Journal of Political Economy 98 (5 Part 2): S71-S102.

Rostow, Walt Whitman. 1960. The Stages of Economic Growth: A Non-Communist Manifesto. Cambridge: Cambridge University Press.

Saunders, Caroline, and Paul Dalziel. 2017. 25 Years of Counting for Nothing: Waring's Critique of National Accounts. Feminist Economics 23 (2): 200-218.

Schischka, John, Paul Dalziel, and Caroline Saunders. 2008. Applying Sen's Capability Approach to Poverty Alleviation Programmes: Two Case Studies. Journal of Human Development and Capabilities 9 (2): 229-246.

Sen, Amartya. 1983. Development: Which Way Now? Presidential Address of the Development Studies Association. Economic Journal 93 (December): 745-762.

- 1993. Capability and Well-Being. In The Quality of Life, ed. Martha Nussbaum and Amartya Sen, 30-53. London/New York: Routledge.

— 1999a. Development as Freedom. Oxford: Oxford University Press. 1999b. Reason Before Identity: The Romanes Lectures. Oxford: Oxford University Press.

Shultz, Theodore W. 1961. Investment in Human Capital. American Economic Review $51(1): 1-17$.

- 1961. Investment in Human Capital. American Economic Review 51 (1): 1-17.

Smith, Adam. 1776. An Enquiry into the Nature and Causes of the Wealth of Nations, 2 vols., University Paperbacks edition, ed. by Edwin Cannan. London: Methuen.

Solow, Robert M. 1956. A Contribution to the Theory of Economic Growth. Quarterly Journal of Economics 70 (1): 65-94.

1974a. Intergenerational Equity and Exhaustible Resources. The Review of Economic Studies 40 (Symposium): 29-45.

1974b. The Economics of Resources or the Resources of Economics. American Economic Review 64 (2): 1-14.

Stiglitz, Joseph. 2012. The Price of Inequality: How Today's Divided Society Endangers Our Future. New York: Norton.

Stiglitz, Joseph, Amartya Sen, and Jean-Paul Fitoussi. 2009. Report by the Commission on the Measurement of Economic Performance and Social Progress. https://www.insee.fr/ en/information/2662494. Accessed 16 July 2017. 
Swan, Trevor W. 1956. Economic Growth and Capital Accumulation. Economic Record 32 (2): 334-361.

Throsby, David. 1999. Cultural Capital. Journal of Cultural Economics 23 (1): 3-12. Treasury. 2004. Policy Advice and Treasury's Wellbeing Framework. Economic Roundup (Winter): 1-20.

Turner, Graham M. 2012. On the Cusp of Global Collapse? Updated Comparison of the Limits to Growth with Historical Data. GAIA - Ecological Perspectives for Science and Society 21 (2): 116-124.

United Nations. 2009. System of National Accounts 2008. Published by the European Commission, the International Monetary Fund, the Organisation for Economic Co-operation and Development, the United Nations and the World Bank.

- 2015. Transforming Our World: The 2030 Agenda for Sustainable Development. New York: United Nations.

Waring, Marilyn. 1988. If Women Counted: A New Feminist Economics. San Francisco: Harper \& Row. Also published as Counting for Nothing: What Men Value and What Women Are Worth. Wellington: Allen \& Unwin in Association with the Port Nicholson Press.

White, Sarah C. 2017. Relational Wellbeing: Re-centring the Politics of Happiness, Policy and the Self. Policy \& Politics 45 (2): 121-136.

Wilkinson, Richard G., and Kate Pickett. 2009. The Spirit Level: Why More Equal Societies Almost Always Do Better. London: Allen Lane.

World Bank. 2011. The Changing Wealth of Nations: Measuring Sustainable Development in the New Millennium. Washington, DC: World Bank Group.

- 2016. World Development Indicators 2016. Washington, DC: World Bank Group.

Xu, Guangdong. 2011. The Role of Law in Economic Growth: A Literature Review. Journal of Economic Surveys 25 (5): 833-871. 
Open Access This chapter is licensed under the terms of the Creative Commons Attribution 4.0 International License (http://creativecommons.org/licenses/by/4.0/), which permits use, sharing, adaptation, distribution and reproduction in any medium or format, as long as you give appropriate credit to the original author(s) and the source, provide a link to the Creative Commons license and indicate if changes were made.

The images or other third party material in this chapter are included in the chapter's Creative Commons license, unless indicated otherwise in a credit line to the material. If material is not included in the chapter's Creative Commons license and your intended use is not permitted by statutory regulation or exceeds the permitted use, you will need to obtain permission directly from the copyright holder.

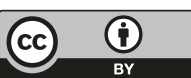

